\title{
KOMUNIKASI ANTAR KELUARGA MUSLIM BEDA BUDAYA DI PALANGKA RAYA
}

(COMMUNICATION BETWEEN DIFFERENT MUSLIM FAMILIES

IN PALANGKA RAYA)

\author{
Ngalimun ${ }^{1)}$ \\ Rahmawati $^{2)}$ \\ Institut Agama Islam Negeri (IAIN) Palangka Raya \\ Jl. G. Obos Kompleks Islamic Centre Palangka Raya 73112
}

\begin{abstract}
This study aims to determine the model of communication between Muslim families of different cultures and inhibiting factors of communication. This research was conducted on couples of five families who married with different cultures in the Tanjung Pinang sub-district, Pahandut sub-district, Palangka Raya City. With the marriage of different cultures is expected to enrich the culture and can also be used as lessons for individuals who want to do the marriage. This type of research is descriptive qualitative, the sample of this study is 5 families. The communication model of 5 Muslim families with different cultures can be seen from the adaptation process that occurs in their respective families. In adapting there are various things that start from the adaptation of the language, through habits, through different food tastes and complement each other so that each family has a different communication model. Whereas the factors which hamper communication in the family are the difficulty of language adjustment, the existence of prejudice, the communication that occurs is oneway or there is no feedback and errors in the evaluation of the message delivered.
\end{abstract}

Keywords: communication, Muslim families, cultural differences 


\section{PENDAHULUAN}

Dalam kehidupan keluarga berbeda budaya ini, akan terjadi satu komunikasi antarbudaya yang melibatkan seluruh anggota keluarga bahkan juga orang yang berada di sekitarnya. Dalam perkawinan beda budaya diperlukan saling pengertian dan saling menerima pasangan masing-masing dengan latar belakang keluarga dan kebiasaan yang berbeda.

Menurut Mulyana (2010) masyarakat heterogen merupakan masyarakat yang memiliki latar kebudayaan, ras dan ideologi yang berbeda. Heterogenisme adalah istilah yang digunakan untuk menjelaskan pandangan seseorang tentang ragam kehidupan di dunia, ataupun kebijakan kebudayaan yang menekankan tentang penerimaan terhadap realitas keragaman, dan berbagai macam budaya (heterogen) yang ada dalam kehidupan masyarakat menyangkut nilai-nilai, sistem, budaya, kebiasaan, dan politik yang mereka anut.

Jadi perubahan sosial pada masyarakat heterogen mempunyai berbagai faktor yang mempengaruhinya. Faktor tersebut dapat berdampak yang kuat pada kehidupan bermasyarakat, baik dampak positif maupun negatif. Tapi itu semua tergantung masyarakat yang menyikapinya, bila masyarakat menyikapi perbedaan budaya, suku, atau ras dengan baik. Maka dampak yang muncul pastilah baik, dan tidak menimbulkan konflik antar suku hanya karena perbedaan budaya. Di Indonesia contohya yaitu menganut Bhineka Tunggal Ika yang berarti walaupun berbeda tapi kita tetap satu jua, jadi kita harus bersatu meskipun kita berbeda. Bukan perbedaan yang memisahkan kita, tapi perbedaan lah yang menyatukan kita.

Budaya berkaitan dengan cara manusia hidup, manusia berpikir dan bertindak sesuai dengan pola budaya yang telah melekat pada dirinya. Sedangkan menurut Littlejohn (1996) budaya menampakkan diri dalam setiap pola bahasa, bentuk-bentuk kegiatan dan perilaku yang memungkinkan setiap inidvidu di dalamnya bertindak dan berkomunikasi sesuai dengan pola budaya yang dianut. Budaya dan komunikasi tidak 
dapat dipisahkan karena seluruh perilaku seseorang sangat bergantung pada budaya tempat ia dibesarkan. Budaya merupakan landasan komunikasi, semakin beranekaragam budaya, maka semakin beraneka ragam pula praktik komunikasi yang dilakukannya.

Kemudian menurut Purba (2018: 43-54) dalam jurnalnya berdasarkan hasil penelitian yang dilakukan menunjukkan bahwa proses komunikasi antar budaya dapat terjalin dengan baik dan efektif diantara keempat pasangan kawin campur. Keseluruhan informan berusaha untuk menghormati dan menghargai perbedaan budaya dalam pernikaha mereka. Mereka berusaha untuk membaur dengan budaya pasangannya. Terjadi perubahan pandangan dunia (agama, nilai-nilai dan perilaku) pada pasangan minoritas dan memilih untuk mengikuti keyakinan pasangan yang lebih dominan.

Fenomena yang terjadi antara keluarga pendatang yang berasal dari berbagai macam daerah ataupun keluarga pribumi yang sudah lama menetap akan terjadi kendala atau kesulitan dalam melakukan interaksi maupun berkomunikasi. Kelurahan Tanjung Pinang banyak didominasi oleh keluarga suku Dayak, Banjar, Jawa dan seperti yang diketahui bahwa dalam berkomunikasi sehari-hari tidak menggunakan bahasa nasional tetapi bahasa daerah.

Perbedaan budaya juga terdapat di kelurahan Tanjung Pinang kota Palangka Raya Kalimantan Tengah. Hasil observasi sementara, lokasi kelurahan Tanjung Pinang ini berada di jalan Bengaris yang berdekatan dengan Bandar Udara Tjilik Riwut kota Palangka Raya. Kelurahan ini berada di tengah-tengah kota namun terlihat seperti sebuah desa karena penduduknya yang masih sedikit. Kegiatan sehari-hari penduduk kelurahan ini bermacammacam ada yang berdagang, bertanam dan mencari ikan di sungai. Selain itu di kelurahan ini juga memiliki penduduk yang berbeda macammacam suku. Salah satu bukti bahwa studi komunikasi antarbudaya banyak digemari 
adalah karena saat ini perkembangan dan pembangunan yang terjadi di Kota Palangka Raya, membuat banyak orang tertarik untuk merantau dan menetap di wilayah ini. Pernikahan antarsuku pun tidak dapat dihindari karena interaksi yang terjadi antara warga asli maupun warga pendatang bahkan sesama pendatang yang berbeda khususnya yang berada di kelurahan Tanjung Pinang Kota palangka Raya.

\section{METODE PENELITIAN}

Secara umum, penelitian ini termasuk dalam jenis penelitian deskriptif kualitatif, yaitu suatu jenis penelitian yang menggambarkan semua data atau keadaan subjek atau objek penelitian (seseorang, lembaga, masyarakatdan lain-lain), kemudian dianalisis secara kualitatif yaitu penelitian yang bermaksud untuk memahami fenomena tentang apa yang dialami oleh subjek penelitian misalnya perilaku, persepsi, motivasi, tindakan dan lain-lain., secara holistik dan dengan cara deskripsi dalam bentuk katakata dan bahasa, pada suatu konteks khusus yang alamiah dan dengan memanfaatkan berbagai metode alamiah. Jenis penelitian deskriptif ini tidak dimaksudkan untuk mengubah data yang disajikan dalam bentuk symbol atau bilangan, tetapi data yang dinyatakan adalah data dalam keadaan kewajaran atau sebagimana adanya (natural setting).

Penelitian ini dilakukan di kota Palangkaraya, tepatnya di kelurahan Tanjung Pinang. Dalam hal ini kemampuan akademik masyarakat tersebut tidak dijadikan batasan agar penelitian tersebut mudah dilakukan. Pertimbangan lokasi karena kelurahan Tanjung Pinang, kota Palangka Raya dinilai memiliki masyarakat yang beraneka ragam dari berbagai suku dan dinilai lebih mudah untuk tinjuan sebagai tempat penelitian karena merupakan kota kelahiran sendiri. 


\section{HASIL PENELITIAN DAN PEMBAHASAN}

\section{Karakteristik Informan}

Selama melakukan penelitian, peneliti melakukan wawancara mendalam kepada 5 keluarga informan, yaitu masyarakat yang tinggal di kelurahan Tanjung Pinang di Jalan Bengaris. Informan-informan ini mampu memberikan data-data yang dibutuhkan peneliti. Saat diwawancarai, mereka sangat baik, ramah, terbuka, dan menjawab semua pertanyaan yang peneliti tanyakan.

\section{Dekskripsi Informan Keluarga}

1. Informan pertama, Bapak HLN dan Ibu HTT yang tinggal di jalan Bengaris $X$ (sepuluh) kelurahan Tanjung Pinang yang menikah pada tahun 1988 di Palangka Raya dengan Bapak Suku Dayak dan Ibu Suku Banjar. Adapun pekerjaan Ibu adalah seorang Guru dan Bapak Swasta. Keluarga ini memiliki 3 (tiga) orang anak. Anak pertama sudah menikah dan anak ke dua dan tiga masih bersekolah di perguruan tinggi.

2. Informan kedua, Bapak ARH dan Ibu WYN yang tinggal di jalan Bengaris $X$ (sepuluh) kelurahan Tanjung Pinang yang menikah pada tahun 2011 di Palangka Raya dengan Bapak suku Jawa dan Ibu suku Dayak. Memiliki 1 (satu) anak yang masih berumur 5 tahun.

3. Informan ketiga, Bapak SGT dan Ibu MNI yang tinggal di jalan Bengaris IX (sembilan) kelurahan Tanjung Pinang yang menikah pada tahun 1997 di Palangka Raya dengan Bapak suku Jawa dan Ibu suku Dayak. Adapun Bapak seorang PNS dan Ibu Bidan. Dengan jumlah anak 3 (tiga) orang yang masih sekolah.

4. Informan keempat, Bapak H. RMD dan Ibu Hj. yang tinggal di Bengaris Induk kelurahan Tanjung Pinang yang menikah pada tahun 1983 di Palangka Raya dengan Bapak suku Sasak dan Ibu suku Jawa. memilik 2 (dua) orang anak perempuan yang sudah menikah. Sedangkan Ibu sebagai Ibu Rumah Tangga (IRT) dan Bapak Swasta. 
5. Informan kelima, Bapak SPN dan Ibu RDJ yang tinggal di Bengaris IX (sembilan) kelurahan Tanjung Pinang yang menikah pada tahun 2011 di Palangka Raya dengan Bapak suku BAnjar dan Ibu suku Jawa. memiliki 1 (satu) orang anak yang masih berumur 4 tahun. Adapun perkerjaan Bapak dan Ibu adalah seorang Guru.

\section{Komunikasi Antar Keluarga Muslim Beda Budaya}

Komunikasi antar keluarga dalam berinterkasi dirumahnya sendiri dapat dilihat dari proses komunikasi antara suami dan istri masingmasing. Berikut adalah hasil wawancara dari masing-masing lima keluarga saat pertama kali berkomunikasi.

\section{Keluarga Bapak HLN dan Ibu HTT}

Menurut Bapak HLN banyak kosa kata baru dalam sehari-hari. "Saya kan orang dayak, dari kecil udah terbiasa kalau berbicara pakai bahasa Dayak. Pertama kali ketemu sama istri masih malu-malu dan minder karena tidak terlalu mengerti bahasa banjar. Tapi setelah menikah istri mau ngajarin saya pakai bahasa banjar".

Wawancara di atas menjelaskan bahwa bahasa dalam kehidupan sehari-hari bapak HLN sangat penting. Awalnya mungkin belum terbiasa menggunakan bahasa lain selain dayak sehingga mendapatkan banyak perubahan setelah menikah dengan istrinya. Di mana ia harus belajar bersama istrinya agar komunikasi mereka bisa berjalan dengan lancar sesuai dengan harapan.

Menurut Ibu HTT kesan pertama kali saat ia berkomunikasi dengan suaminya ia merasakan perubahan dalam berbahasa. “Aku Orang Banjar, suamiku orang Dayak. Tiap hari saya berbicara bahasa Banjar. Pertama kali komunikasi sama suami, saya pernah keceplosan memakai bahasa Banjar. Dan itu membuat suami saya terkejut dengan bertanya apa itu artinya. Karena diawal kami bertemu, kami selalu menggunakan bahasa Indonesia"

Dari wawancara di atas dapat dijelaskan bahwa ketika seseorang berkomunikasi dengan orang yang tidak mengerti dengan apa yang ia ucapkan, maka 
komunikasi itu tidak dapat diterima sebagai informasi oleh si pendengar. Hal itu dikarenakan si pendengar tidak mengerti dengan maksud apa yang diucapkan oleh pembicara. Begitu juga dengan yang dialami oleh ibu HTT ketika berkomunikasi dengan suaminya yang tidak mengerti bahasa banjar yang pada awalnya sangat kebingungan ketika ia mendengar sang istri berbicara menggunakan bahasa banjar.

\section{Keluarga Bapak AHT dan Ibu WYN}

Menurut Ibu WYN mengatakan saat pertama kali berkomunikasi dengan suami biasa saja. "Karena kan waktu pertama kali bertemu dengan suami selalu berkomunikasi menggunakan bahasa Indonesia. Jadi sampai menikah pun kami selalu menggunakan bahasa Indonesia. Tapi sekarang kami sudah mulai belajar bahasa daerah masingmasing agar lebih nyaman dalam berkomunikasi".

Dari wawancara di atas, dapat dijelaskan bahwa bahasa yang berbeda tidak menjadi penghambat satu sama lain untuk bekomunikasi. Hal itu dikarenakan masih ada bahasa yang sama bisa digunakan dalam berkomunikasi bagi dua suku yang berbeda yaitu bahasa Indonesia.

Menurut Bapak AHT pun mengatakan biasa saja. “Biasa aja. karena saya masih bisa sedikit berbahasa Dayak. Jadi agak mudah berkomunikasinya.

Dalam wawancara lain yang peneliti lakukan dengan Ibu WYN cara beradaptasi dengan suaminya adalah dengan belajar memahami. "Suami saya itu orangnya manutmanut saja kalau apa-apa. Jadi saya yang belajar memahami kehendaknya dirumah. Saya masak ini masak itu dia tidak protes. Kadang saya bertanya mau makan apa hari ini dia jawab terserah istri saja mau masak apa katanya begitu. Karena suami sudah melimpahkan semuanya ke saya, jadi saya pun berusaha untuk memahaminya agar kami tetap nyaman satu sama lain".

Dapat dijelaskan bahwa pemahaman dalam sebuah keluarga antara suami dan istri itu sangat perlu. Kalau suami tidak dapat memahami maka istrilah yang mengalah 
harus dapat memahami suaminya begitu juga sebaliknya agar tidak ada sebuah kesalahpahaman yang terjadi dan komunikasi tetap bisa berjalan dengan baik. Sedangkan menurut Bapak AHT agar komunikasi tetap harmonis adalah: "Saling percaya saja kepada pasangan masing-masing. Karena mau ngomongin apa aja pakai bahasa yang berbeda bisa membuat kita dan pasangan kita terhibur. Seperti saya kalau lagi merayu istri menggunakan bahasa jawa seperti ini "Kula remen marang panjenengan" dan itu sangat menghibur istriku asalkan ia percaya dengan terjemahannya (sambil tertawa). Dapat dijelaskan bahwa saling percaya juga merupakan kunci agar komunikasi dalam sebuah keluarga tetap bisa berjalan harmonis. Walaupun terdapat perbedaan bahasa bukan berarti tidak ada komunikasi. Tetap ada komuniksi hanya saja digunakan saat yang tepat. Terlihat saat komunikasi terjadi antara Bapak AHT dan istrinya memang terjadi seperti yang diungkapkan keduanya.

Jadi dari hasil wawancara diatas dapat dijelaskan bahwa bahasa yang berbeda tidak dapat menghalanginya jalannya sebuah komunikasi. Hal itu dikarenakan adanya kepahaman dan kepercayaan antara satu dengan yang lainnya dalam berkomunikasi. Maka dapat disimpulkan dalam keluarga ini seperti model S-C-M-R (berlo) yang menggambarkan hubungan antara pengirim pesan dan penerima pesan. Walaupun ada hambatan-hambatan komunikasi mungkin saja terjadi dan berdampak pada respon atau tanggapan yang diberikan oleh penerima pesan. Hambatan-hambatan itulah yang akan mempengaruhi proses untuk membuat komunikasi menjadi lebih efisien.

\section{Keluarga Bapak SGT dan Ibu MNI}

Menurut Bapak SGT harus banyak belajar semua bahasa. "Karna saya seorang RW (rukun warga) disini, saya harus dekat dengan warga yang lainnya. Jadi saya harus memiliki kemampuan berbahasa yang baik agar komunikasi diluar juga baik. Saat 
pertama kali berkomunikasi dengan istri pun saya sudah mengerti dengan bahasa yang digunakannya. Jadi tidak terlalu membuat saya susah untuk berkomunikasi".

Dari wawancara diatas, dapat dijelaskan bahwa kemampuan dalam berbahasa apa saja sangat diunggulkan karena itu sangat berguna untuk sesuatu yang penting atau memang diperlukan saat waktunya diperlukan dan digunakan karena bahasa merupakan salah satu kunci agar semua orang bisa berkomunikasi. Terlihat memang bapak SGT ini merupakan RW yang sangat menjaga bahasanya terutama saat ia berkomunikasi dengan warga. Bahkan bapak SGT ini setiap kali berkomunikasi dengan warganya menyesuaikan bahasa yang digunakan lawan bicaranya.

Agar komunikasi tetap harmonis menurut Bapak SGT adalah saling terbuka. “Namanya juga nikah beda suku ya pasti ada perbedaan dalam rumah tangga atau di dalam sebuah keluarga. Seperti saya dan istri saya yang berbeda bukan berarti kami tidak bisa berkomunikasi. Kami masih bisa berkomunikasi dengan menggunakan bahasa yang sama-sama kami bisa yaitu bahasa Indonesia. Terkadang dalam keluarga itu penting sekali keterbukaan, karena katerbukaan itulah yang bisa membuat kami saling mengetahui agar tidak terjadi kesalahan fatal yang tidak ingin kami harapkan dalam keluarga dan itulah juga kenapa rumah tangga kami tetap harmonis".

\section{Keluarga Bapak H. RDN dan Ibu Hj. AKK}

Menurut H. RDN kesannya saat pertama kali menggunakan bahasa lain selain sasak ialah: "Saya merasa masih bingung dan canggung saat pertama kali berkomunikasi dengan istri untuk pertama kalinya. Walaupun dalam rumah menggunakan bahasa Indonesia tetapi logat saya saya ketika berbicara terkadang membuat istri saya tertawa".

Bapak H. RDN ini lahir di NTB, Lombok. Bahasa sehari-hari beliau sebelum pindah ke kota Palangka Raya adalah bahasa sasak yang merupakan bahasa asli dari daerahnya. Diwaktu yang sama H. RDN mengatakan: “Cara saya beradaptasi dengan 
istri yang saya lakukan adalah pertama kali mengenal bahasa yang digunakan. Karena bahasa yang saya gunakan dan istri saya gunakan sangat jauh berbeda. Isrti saya pun tidak mungkin mengikuti bahasa saya yang begitu rumit. Jadi saya beradaptasi melalui selera makanan istri saya dan terkadang istri mengikuti selera makanan saya. Kalau kami tidak memiliki selera makanan satu sama lain, maka kami akan masak sendirisendiri".

Dari wawancara diatas dapat dijelaskan bahwa cara beradaptasi dengan keluarga bukan hanya terletak pada bahasa saja melainkan juga dari segi selera makan yang juga termasuk didalamnya. Bagaimana cara menggabungkan dua bahasa yang berbeda dan juga dengan selera masakan yang berbeda.

Menurut $\mathrm{Hj}$. AKK pertama kali saat berkomunikasi dengan suaminya adalah: “Pertama kali berkomunikasi dengan suami, saya merasa lucu aja gitu. Karena suami saya waktu itu hanya bisa menggunakan bahasa Sasak dan bahasa Indonesia. Jadi sertiap berkomunikasi saya selalu menggunakan bahasa Indonesia". Dikesempatan lain, Ibu Hj. AKK juga mengatakan: “Cara agar dalam keluarga kami tetap harmonis yaitu kami saling mengerti perbedaan masing-masing, sama-sama belajar dan samasama mengalah. Anak-anak pun tetap kami ajarkan walaupun ada perbedaan bukan berarti tidak sama, tapi tetap sama. Dalam artian bahasa yang digunakan adalah bahasa yang sudah menjadi sehari-hari kami sekarang yaitu bahasa Banjar. Walaupun suami Sasak, saya Jawa bukan berarti kami harus menuntut satu sama lain dan anakanak harus bisa bahasa kami".

Dari wawancara di atas dapat dijelaskan bahwa dalam setiap keluarga yang berbeda dari segi bahasa dan suku harus saling mengerti akan perbedaan masingmasing pasangan. Hal ini bertujuan agar tercipta keluarga yang harmonis. 


\section{Keluarga Bapak SPN dan Ibu RDJ}

Bapak SPN mengatakan saat pertama kali berkomunikasi dengan istrinya adalah: "Saya merasa biasa saja karena sebelum menikah sudah pernah berkomunikasi satu sama lain karna kita mengajar di sekolah yang sama". Dapat dijelaskan bahwa komunikasi berbeda budaya dapat diatasi dengan sering bertemu dan berkomunikasi. Karena hal-hal ini dapat membuat satu sama lain terbiasa hingga akhirnya.

Ibu RDJ saat berkomunikasi dengan suaminya saat pertama kali adalah biasa saja. "Seperti kata suami saya tadi, karena kami sudah terbiasa berkomunikasi karena kami mengajar disekolah yang sama. Jadi setiap berkomunikasi di rumah dengan di sekolah sama saja. Hanya saja yang membedakan kalau di rumah lebih romantis dibandingkan di sekolah." Dapat diterangkan karena sudah terbiasa maka akhirnya menjadi biasa. Seperti itu pulalah sebuah komunikasi yang awalnya belum terbiasa dengan bahasa yang berbeda, namun pada akhirnya akan menjadi terbiasa karena sering melakukan komunikasi bersamsama. Adapun diwaktu yang sama, bapak SPN mengatakan: "Karena saya sudah mengenal istri sebelum menikah jadi saya tidak terlalu beradaptasi melalui bahasa untuk komunikasi kami setiap hari. Tetapi saya lebih memilih beradaptasi dengan kebiasaan istri saya setiap hari. Karena itulah yang saya lihat setiap hari dari saya bangun tidur sampai saya tidur lagi."

Dari wawancara di atas dapat dijelaskan bahwa bapak SPN beradaptasi dengan istrinya dengan melalui kebiasaan-kebiasaan yang dilakukan istrinya setiap hari di rumah. Jadi beradaptasi tidak hanya dengan bahasa, tetapi juga dengan kebiasaankebiasaan saat sebelum menikah hingga menikah. Misalnya seperti saat makan yang tidak bisa lepas dari sambal, maka dari situlah sang suami harus mengerti jika istri tidak bisa makan tanpa sambal.

Menurut Ibu RDJ, Keharmonisan dalam keluarga bisa terjadi apabila kita bisa saling menerima satu sama lainnya. "Kunci dari sebuah keharmonisan dalam sebuah 
keluarga apabila dalam keluarga tersebut mau menerima kekurangan dan kelebihan serta kebisaan dan ketidakbisaan. Sama halnya saya dan suami sama-sama dari suku yang berbeda bahasa yang berbeda tapi karena kami mau sama-sama menerima kenyataan tersebut dan sama-sama mau belajar kami bisa hidup bersatu dalam sebuah keluarga walaupun bahasa kami berbeda".

Dari wawancara di atas dapat disimpulkan bahwa selain bahasa yang berbeda, saling menerima kekurangan dan kelebihan juga dapat membuat sebuah keluarga menjadi harmonis.

Dalam komunikasi antara orang tua dan anak, Ibu RDJ mengatakan: "komunikasi kami sebagi orang tua dengan anak tidak terlalu memfokuskan bahasa apa saja yang dipakai. Dalam sehari-hari kami hanya menggunakan bahsa banjar dalam berkomunikasi." Komunikasi keluarga dengan lingkungan sekitar, bapak SPN mengatakan: "Alhamdulillah selama kami disini, kami tidak pernah memiliki kendala dalam berkomunikasi dengan tetangga atau warga lainnya. Karena tetangga-tetangga disekitar sini rata-rata masih mayoritas orang banjar."

Dari hasil wawancara di atas dapat dijelaskan bahwa, tidak ada kendala dalam berkomunikasi karena masih dalam penggunaan bahasa yang sama dalam sehari-hari. Maka dapat disimpulkan dalam keluarga ini seperti model interaksional yaitu komunikasi yang dikembangkan melalui interaksi sosial. Mengapa demikian, karena dalam komunikasi yang terjadi dalam keluarga ini didalam maupun diluar terdapat umpan balik dari lingkungan terdekatnya. Adanya umpan balik inilah yang membantu untuk mengetahui sejauh mana pesan telah disampaikan dan sejauh mana pencapaian makna terjadi. 


\section{KESIMPULAN}

Dari penelitian yang didapat tentang Komunikasi Keluarga Muslim Beda Budaya di Palangka Raya terdapat perbedaan pemikiran yang disebabkan sudut pandang serta pengalaman peneliti. Model komunikasi 5 keluarga Muslim beda Budaya di jalan Bengaris RT 04 RW 01 kelurahan Tanjung Pinang dapat dilihat dari proses adaptasi yang terjadi dalam keluarga masing-masing pihak tersebut. Dari pengakuan 5 keluarga, dalam beradaptasi bermacam-macam bentuk ada yang memulai dari penyesuaian bahasa yang digunakan, melalui kebiasaan sehari-hari, melalui selera makanan yang berbeda, serta saling melengkapi satu sama lain. Sehingga membuat lima keluarga ini berhasil membangun komunikasi yang harmonis walaupun terdapat bahasa atau kebiasaan yang berbeda dalam sebuah rumah tangga atau keluarga. Dari 5 keluarga muslim ini memiliki model komunikasi yang berbeda diantaranya adalah 3 Model Interaksional, 1 Model Shannon dan Weaver, dan 1 Model S-C-MR (model berlo).

\section{DAFTAR PUSTAKA}

An-Nahwi, Abdurrahman. 1995. Terj. Heri Nur Ali. Pendidikan Keluarga Islam di Rumah Sekolah Masyarakat. Jakarta: Gema Insani Press.

Damarastuti, Rini. 2013. Mindfulness Dalam Komunikasi Antarbudaya. Yogyakarta: Buku Litera.

Lamry, Mohamed Salleh. 1997. Komunikasi dan Kigrasi: Peranan Keluarga, Kawan, Calo dan Tekong dalam Proses Migrasi Pendatang Indonesia ke Malaysia. Jurnal Komunikasi: Malaysian Journal of Communication. Vol. 1314. e-ISSN: 2289-1528. Indexed SCOPUS Q-3, SJR 0,19.

Littlejohn, Stephen W, 1996. Theories of Human Communication. Belmont, California: Wadsworth. 
Lull, James, 1998. Media Komunikasi Kebudayaan. Suatu Pendekatan Global. Terjemahan: A. Setiawan Abadi. Jakarta: Yayasan Obor Indonesia.

Mulyana, Deddy. 2010. Komuniksi Antar Budaya Panduan Berkomunikasi Dengan Orangorang Berbeda Budaya. Bandung: Remaja Rosdakarya.

Ngalimun. 2018. Komunikasi Antarbudaya. Yogyakarta: Pustaka Pelajar

Purba, Agustina Christin. 2018 Komunikasi Antar Budaya Dalam Keluarga Kawin Campur Terhadap Pola Mendidik Anak Di Komplek Citra Garden Medan. Jurnal Lensa Mutiara Komunikasi, e-ISSN: 2579-8332. Vol. 1 No. 1. Hal 43-54. Indexed PHP

Sanadi, Debora Ria. 2014. Komunikasi Interpersonal pada Keluarga Beda Budaya. Jurnal The Messenger: Culture Studies, IMC and Media. e-ISSN: 2527-2810. Vol. 6. No. 1. Indexed SINTA-2.

Syumanjana, Hanny. 2009. Familly Discovery Way Panduan Manajemen Keluarga yang Berkualitas. Jakarta: Gramedia Pustaka Utama. 
